\title{
Homophobia and national collective narcissism in populist Poland
}

\author{
Richard C.M. Mole, Agnieszka Golec de Zavala and Mahmut Murat Ardag
}

\begin{abstract}
Opposition to sexual minority rights in Poland is among the highest in the EU. Populist political actors in the country repeatedly scapegoat gays and lesbians, presenting them as a threat to the Polish nation and its shared norms and values, particularly those derived from religion. Building upon previous research which shows how discourse constructing homosexuality as a threat to the nation has been used by social and political actors to legitimize homophobic rhetoric and behaviour, our paper aims to show whether nationalism - understood here as national collective narcissism - predicts prejudice towards gays and lesbians at the level of individual beliefs.
\end{abstract}

\section{Key words}

collective narcissism, homophobia, nationalism, Poland, populism

\section{Introduction}

In July 2019 the Polish city of Białystok held it first ever Equality Parade. What was meant to be a public demonstration of support for sexual diversity quickly descended into violence, with thousands of far-right protestors throwing rocks and bottles at the marchers, while chanting 'God, honour and motherland'. ${ }^{1}$ The attackers' appeals to religion and the nation chimed with public proclamations by representatives of the Polish Catholic Church and the ruling Law and Justice Party (Prawo i Sprawiedliwość or PiS): on the day of the march, Białystok's Archbishop Tadeusz Wojda called upon the city's residents to defend Christian values by attending a family picnic in one of the city parks, while, in the run-up to the European Parliament elections a few months earlier, Jarosław Kaczyński, the leader of the populist PiS party, referred to the LGBT rights movement as 'a foreign import that threatens the Polish

1 John T and Darwish M (2019) Polish city holds first LGBTQ pride parade despite far-right violence. CNN, 21 July. Available at: https://edition.cnn.com/2019/07/21/europe/bialystok-polish-lgbtq-pride-intl/index.html. Accessed: 26 September 2019. 
nation' ${ }^{2}{ }^{3}$ Kaczyński's statement is indicative of the centrality of nationalism in Polish debates about the position of $\mathrm{LGBT}^{4}$ individuals in Poland, where nationalism is understood to refer to 'the cultural idea of the nation as one's primary identity, and a moral idea of justification of action to protect the rights of the nation against the other' (Barrington 1997: 713). While opposition to LGBT rights among Poles has lessened in recent years, it is still among the highest in the EU. ${ }^{5}$ The aim of this article is therefore to explain prejudice towards homosexuals among Poles with reference to the belief that gays and lesbians pose a threat to the nation.

Our paper builds on previous research which shows how discourse constructing homosexuality as a threat to the nation and its national identity has been used to legitimize homophobic rhetoric and behaviour (Mole 2011, Mole 2016). However, such research does not show whether nationalism predicts homophobia at the level of individual beliefs. ${ }^{6}$ While our study is not the first to seek to explain homophobia with reference to nationalism, we argue that

2 ibid.

3 'Party Leader Calls LGBT Rights an Imported Threat to Poland', Voice of America, 25 April 2019. Available at: www.voanews.com/europe/party-leader-calls-lgbt-rights-importedthreat-poland. Accessed: 24 September 2019.

4 While the specific focus of our research is gays and lesbians, we refer to the broader LGBT community when discussing social attitudes towards both sexual and gender minorities in Poland. This is not to suggest that our findings can necessarily be applied to bisexual and trans* individuals.

5 See Eurobarometer on Discrimination 2019: Social Acceptance LGBTI People in the EU: Available at: https://ec.europa.eu/commfrontoffice/publicopinion/index.cfm/survey/getsurveydetail/instruments/special/surveyky/2251. Accessed: 26 September 2019.

6 We acknowledge that the concept of 'homophobia' - commonly understood as the 'irrational fear or intolerance of homosexuality or homosexual persons' (Herek 1986: 563) - is controversial as it psychologises prejudice against homosexual people in the sense that 'an irrational fear' is not the fault of the person exhibiting the phobic reaction. In addition, phobias are generally understood to be individual phenomena, whereas homophobia can be promoted by groups and governments, as is the case in Poland. In this article, we use 'homophobia' in a broad sense to refer to negative attitudes towards sexual minorities. 
the latter concept is too broad to explain why attitudes towards gays and lesbians should be related to people's beliefs about their nation. We also argue that not all positive beliefs about a nation are related to homophobia. To say that an individual is 'nationalist' can mean a host of different things depending on the context. Drawing on research in social psychology, we therefore seek to provide greater nuance by differentiating between 'national in-group satisfaction' and 'national collective narcissism'. We explain the distinction below.

National in-group satisfaction is the belief that membership of the nation is valuable and a source of pride and satisfaction. It is associated with high self-esteem, pro-sociality and intergroup tolerance. In other words, the nation and its achievements make members of the nation feel good about themselves and they have an inclusive attitude towards minorities within the nation as well as a co-operative approach in international relations (Golec de Zavala, Dyduch-Hazar \& Lantos, 2019; Golec de Zavala and Lantos 2020). In the context of populist Poland, however, we argue that the dominant nationalist discourse is best captured by the concept of 'national collective narcissism', a concept introduced by Fromm (1964) and Adorno (1997) as narcissism elevated to the level of the group. In more contemporary work it is defined as the 'belief that one's own group (the ingroup) is exceptional and entitled to privileged treatment but it is not sufficiently recognized by others' (Golec de Zavala et al. 2019: 37; see also Cichocka \& Cisłak 2020, Federico, Golec de Zavala \& Baran, 2021). ${ }^{7}$ We suggest that this distinction will provide sociologists of nationalism with greater nuance in their understanding of the different contents nationalist discourse can have and their different associations with attitudes towards minorities.

In addition, while there exists a rich sociological literature on nation formation and reproduction (Gellner 1983, Anderson 1983, Smith 1986, Brubaker and Cooper 2000, Fox and MillerIdriss 2008), these works are less successful at explaining the co-existence of different nationalistic beliefs at the level of the individual. We hope that our research could advance research on societal processes through which some of those beliefs become dominant and define the discourse about the national identity at a given time.

7 For other psychological studies on definitions of nationalism and national identity, see Adorno, Frenkel-Brunswik, Levinson and Sanford 1950; Kosterman and Feshbach 1989; Schatz, Straub, \& Lavine 1999. 
In the first part of the article we present the social and historical context of our case study, analysing the upsurge in nationalism in the early post-communist years and the rise of populism in the new millennium, highlighting how the merging of the two ideologies resulted in the dominant definition of nationalism in Poland taking the form of national collective narcissism. We then discuss the ways in which different actors sought to attach specific meaning to non-normative sexualities, before analysing the perceived relationship between nationality and homosexuality in a bid to explain theoretically why nationalists tend to exhibit high levels of hostility towards sexual minorities. Following the presentation of our methodology, we set out and then discuss the results of the studies and draw overall conclusions.

\section{Case study: homophobia in post-communist Poland}

When examining non-normative sexualities in specific geographical contexts, it is important to remember that the meaning attached to sexuality is culturally and historically contingent. As Jeffrey Weeks explains, 'homosexuality, like all forms of sexuality, has different meanings in different cultures - so much so that it becomes difficult to find any common essence which links the different ways it is lived' (1992: xi). Homosexuality in Poland thus has its own history, its own meanings, its own culture and its own language. Space prevents us from analysing the latter in detail but we recommend further reading in the footnote. ${ }^{8}$ For the purpose of our argument, we will limit the analysis below to the politicisation of homophobia after 1989.

8 See Kościańska A (2020) Gender, Pleasure and Violence. The Construction of Expert Knowledge of Sexuality in Poland. Bloomington, Indiana University Press; Mizielinska J (2011) Travelling Ideas, Travelling Times: On the Temporalities of LGBT and Queer Politics in Poland and the 'West'. In: Kulpa R and Mizielisnka J (eds) Decentring Western Sexualities. Central and Eastern European Perspectives. Farnham: Ashgate, 85-106; Górska A (n.d.) Kalendarium LESteśmy w Polsce. Available at: http://www.porozumienie.lesbijek.org/KalendariumLestesmyPolska.htm. (Accessed 22 September 2020) 
Poland was unique in the communist bloc in never having criminalized homosexuality. ${ }^{9} \mathrm{Nev}-$ ertheless, same-sex relations were presented by the regime as 'a symptom of 'Western depravity' and as inconsistent with 'socialist morality' (Kliszyński 2001: 161), with the Civic Militia and Security Services often keeping tabs on gay men with a view to using their homosexuality 'as a means of recruitment or blackmail' (Tomasik 2012: 20). Following the collapse of communism in 1989, life for LGBT Poles certainly improved. They had less to fear from the state, and gay and lesbian venues opened throughout the country - at least in the larger cities. However, the long-hoped-for liberation for LGBT Poles soon came into conflict with attempts to redefine Polish identity after 50 years of communist rule.

The 1990s in Poland was a period of massive upheaval and uncertainty. Not only did the Soviet-style economic system need to be dismantled and new democratic political institutions rebuilt from scratch but a new cognitive framework had to be found through which citizens could make sense of the world around them and guide their decisions about whom to trust and with whom to co-operate. In this context, nationalism provided Poles with a sense of cohesion and stability in that it offered a credible explanation of the past and a guide for the present and the future. (It should be noted that this was true of many other post-communist societies; see Mole 2011.) In many ways, it was the past that served as the guide for the present and the future. In rejecting the hated communist era, Polish political elites harked back to the inter-war Second Republic and its traditional norms and values. As this period was held up as the opposite of the abnormal communist era, traditional was equated with normal, with traditional gender and sexual roles seen as 'an important aspect of the nostalgia for 'normality" (Watson 1993: 472-3). However, what was seen as 'normal' was defined strictly in national, Catholic and heterosexual terms. In the Polish context, the three concepts are largely understood as indivisible: to be Polish is to be Catholic and heterosexual. In the search for stability, any form of diversity can seem threatening (Inglehart and Baker 2000: 28). In Central and Eastern Europe, there was thus a tendency among individuals disoriented by the social, economic and political upheaval to 'cling to traditional gender roles and sexual norms, and

9 No laws criminalizing homosexual activity between consenting adults were ever introduced in independent Poland, although such laws were enacted on Polish territory by the occupying powers during the partition (1795-1918) and remained in force until 1932. 
emphasize absolute rules and familiar norms in an attempt to maximize predictability in an uncertain world' (Inglehart and Baker 2000: 28). The framing of non-normative sexualities and gender identities as a threat to the Polish nation was thus evident from the early postcommunist period and remained a key discursive trope among church leaders and nationalist politicians over the decades that followed.

Having acted as the de facto political opposition to the Communist Party throughout the period of state socialism, the Polish Catholic Church acquired even greater legitimacy and political power after 1989, establishing its hegemony as the ultimate arbiter of national values, particularly with reference to issues of gender and sexuality. Far from restricting its views to the pulpit, the Catholic Church actively lobbied successive Polish governments in the 1990s to ensure that their position on issues relating to sexuality was in line with Catholic dogma. According to former MP Robert Biedron', the Church succeeded, for example, in ensuring there was no reference to sexual orientation in the non-discrimination clause of the Polish Constitution (Selinger 2008: 25).

The safeguarding of traditional sexual and gender norms emerged as a major campaign issue in Polish politics following the country's accession to the European Union in 2004. Given the latter's introduction of various measures aimed at promoting the legal equality of sexual minorities, nationalist politicians in Poland constructed the EU as elitist and out-of-touch, with its more liberal position towards LGBT rights seen as a threat to traditional Polish values (Graff 2010). Not only did right-wing political actors seek to limit EU support for the promotion of LGBT rights in Poland, however; they also promoted 'a new East to West evangelism', seeking to 'maintain and spread Catholic values via their return to Europe' (Ayoub 2016: 171). ${ }^{10}$ In his research Ayoub demonstrates that 'religion plays a role in moderating the effect of international LGBT norms, but only in contexts where it has become linked to the popular nation' (Ayoub 2016: 162). As we argue above, Poland is an example of the fusion of religion and nation par excellence. This relationship also helps explain why homophobia is higher in some Catholic countries of Eastern Europe, such as Lithuania, than others, such as Slovenia.

10 For example, the Polish government lobbied hard for Christianity and Christian values to be recognized in the Constitution of the European Union (see Eberts 2005: 167). 
In the run-up to the 2005 parliamentary elections, nationalist parties used the issue of LGBT rights to construct an us-versus-them dichotomy between the 'decadent West' and 'traditional Poland', the latter grounded in the true European values of Christian morality, with attitudes towards sexuality becoming 'a reference point for political self-definition and national pride' (Graff 2010: 584). Following criticism from the European Parliament over its failure to respect the rights of its LGBT citizens (European Parliament 2007), it became a matter of sovereignty that Poland be allowed to criticise sexual minorities, with homophobia becoming 'the new voice of patriotism' (Graff 2010: 590). Further research clarified that it is national collective narcissism, rather than patriotism, that is related to homophobia in Poland (Górska \& Mikołajczak, 2015).

The discursive trope of 'homosexuality as a threat to the nation' became so hegemonic among opponents of same-sex rights in Poland by the late-1990s/mid-2000s that Polish activists were prompted into a strategic response, whereby they reframed support for LGBTQ equality from being a universal human rights and Europeanisation issue to 'a more rooted politics of being Polish' (Ayoub and Chetaille 2020: 22). As Ayoub and Chetaille explain, 'activists were inclined to use national symbols such as the Polish flag' in a bid to reclaim Polish national identity for sexual minorities, while the choice of 'Love thy neighbour' as the theme of the 2007 Equality Parade in Warsaw was meant to resonate with Catholic values and 'national identity and root the movement in the local context' (Ayoub and Chetaille 2020: 33).

With reference to Warsaw's relations with Brussels, the 'pure Poles v. elitist EU' rhetoric employed by PiS politicians signalled the shift towards populism in the party's political strategy. While it is a contested concept, populism is used here to refer to 'a thin-centred ideology that considers society to be ultimately separated into two homogenous and antagonistic camps, "the pure people" versus "the corrupt elite," and which argues that politics should be an expression of the volonté generale (general will) of the people' (Mudde and Rovira Kaltwasser 2017: 6). As a thin ideology, populism is always 'thickened' by being grafted onto other ideologies, so as to ensure the political message appeals to the broadest-possible audience in the specific local context.

Populism appeals particularly to the left behind, those who failed to benefit from the economic policies championed by neoliberal politicians or who feel disorientated by the rapid social and cultural change brought about by globalization (Inglehart and Norris 2016). Such 
economic, social and cultural change often results in a loss of status for members of previously advantaged groups and, at the same time, greater empowerment for women and sexual and ethnic minorities. Taken together, these processes undermine the sense of entitlement of formerly privileged individuals, which populists promise to restore 'by offering backwardly oriented utopias and historical narratives that glorify traditional communities with ethnic, national and cultural homogeneity' (Salmela and von Scheve 2017: 577). To achieve this goal, populism in the Polish context is thickened with nativist nationalism, which 'alludes to the notion that states should be inhabited exclusively by members of the native group ("the nation") and that non-native ("alien") elements are fundamentally threatening to the homogenous nation-state' (Mudde \& Rovira Kaltwasser 2017: 34).

In contemporary Poland, the shift towards populism and ensuing nativist redefinition of the nation have resulted in Polish nationalism harvesting national collective narcissism as a predominant narration about Polish national identity (Federico et al., 2021; Golec de Zavala, Lantos \& Keenan, 2021). According to psychological research, collective narcissists demand privilege for the nation, not equality, and invent enemies both inside and outside the national ingroup, whom they blame for standing in the way of this privilege being achieved. Collective narcissism is linked to an exclusive and narrow definition of who can be a 'true' member of the in-group, whereby national collective narcissists do not consider minorities as equally valued members of the nation but rather as a threat to its identity.

As the quote by Kaczynski in the introduction demonstrates, it is not just ethnic minorities that are considered to be a threat to the Polish nation and its identity but also LGBT individuals. Populist politicians in Poland use the supposed alien-ness of homosexuality and its association with Western values to portray LGBT people as disloyal enemies of the state. Even more vociferously, they have sought to portray homosexuals as a threat to the nation and its values (O'Dwyer and Vermeersch 2016). So why do they see homosexuality as a threat to the nation? What is the mechanism through which nationalism fuels homophobia? To answer these questions, we must examine the theoretical literature on the relationship between the nation and homosexuality. 


\section{Homosexuality as a threat to the nation ${ }^{11}$}

The first thing to make clear when discussing the relationship between the nation and homosexuality is that there is no a priori relationship between the nation and homosexuality. It is perfectly possible for individuals for whom membership of the nation is an important part of their self-definition to be fully accepting of gays and lesbians. ${ }^{12}$ However, history has shown that those who understand the nation to be a natural phenomenon, growing out of extended kin groups, are more likely to support a patriarchal gender order and absolute rules on sexuality and are thus more likely to oppose homosexuality (Nagel 2000; Nagel 2003). Right-wing populists inspired by national collective narcissism tend to adhere to this understanding of the nation. Our review of the existing theoretical literature identified four key threats that homosexuals are believed to pose to the nation: (i) they fail to contribute to its biological reproduction; (ii) they fail to contribute to its cultural reproduction; (iii) they fail to adhere to national stereotypes of masculinity and femininity; and (iv) they deviate from shared national norms, especially those derived from religious teaching.

The biological reproduction of the nation is maintained by means of the patriarchal family, underpinned by heteronormative and patriarchal conceptions of masculinity and femininity. The most important role that women can play in the nation is that of the mother, producing sons and daughters for the nation and inculcating in them the ethnic language and culture, while men act as defenders and decision-makers. As the focus on the biological reproduction of the nation presupposes it to be heterosexual, gays and lesbians - by not having children undermine the idea of the nation as a unified collectivity with a communal future (Yuval-Davis 1996). The construction of gay men as weak and effeminate and lesbians as strong and masculine confuses the patriarchal gender order and the public and private roles of men and women central to most ethno-national discourses (Nagel 1988).

To maintain a clear boundary and hierarchical relationship between the Self and Other, nationalism works to convey the idea of internal homogeneity through shared norms and values.

11 A more detailed explanation of the relationship between nationalism and homophobia can be found in Mole (2016).

12 Indeed, nationalist movements in a number of states, such as the Netherlands, Belgium, and the UK, support LGBT rights, albeit with homonationalist agendas (see Puar 2007). 
In his seminal work on nationalism and sexuality George Mosse shows how 'nationalist ideologies which arose in late eighteenth and early nineteenth-century Europe were associated with attempts on the part of national bourgeoisies to create national collectivities in their own image. This image was grounded in a specific gender division of labour, sexual orientation and ethnicity which involved notions of respectability and appropriate sexual behaviour' (in Charles and Hintjens 1998: 2). Heterosexuality therefore became a taken-for-granted attribute of the nation and dominant group norm, against which actions and beliefs were judged.

Homosexuality is seen not just as deviating from but actually threating the norms on which the nation is built. In terms of nation-building, the presence of gay men threatens the homosocial male bonding required to forge the nation and defend it militarily, while homosexuals are also perceived as not possessing the typically masculine virtues of 'willpower, honour, courage' needed to inspire action in the name of the nation (Nagel 1998: 245; see also Slootmaeckers 2019). As Mosse argues, the 'ideal of masculinity [...] as a symbol of personal and national regeneration' requires a countertype, an Other lacking in masculinity, against which the normative masculine ideal is strengthened and legitimized (1996: 4). These countertypes, of which homosexuals are a key group, do not just represent different types of masculinity but are constructed as 'enemies', whereby the 'line between modern masculinity and its enemies had to be sharply drawn in order that manliness as the symbol of a healthy society might gain strength from this contrast' (Mosse 1996: 67-68). ${ }^{13}$ Violence towards public manifestations of (what are perceived to be) the effeminacy and unmanliness of homosexual men is therefore legitimized with reference to their 'enemy' status. Homosexuality is dangerous because it blurs the clearly defined and stoutly maintained 'distinction between normality and abnormality' (Mozaīka 2007: 30), which, according to Mosse, has always 'provided the mechanism that enforced control and ensured security' (1985: 10).

In Poland one of the powerful national norms is religious adherence, another factor explaining opposition to LGBT rights. Throughout the centuries the words of St Paul (Romans I: 26-28) have been used to condemn homosexuality. Indeed, the main branches of the Christian

13 In addition to homosexuals, other countertypes have historically included Jews, Gypsies, vagrants, habitual criminals and the insane (Mosse 1996: 12). 
Church in Central and Eastern Europe have been vocal in their condemnation of non-heteronormative sexuality. The current position of the Catholic Church to homosexuality is closely tied to procreation. Same-sex acts are considered sinful in that sexuality is presented as being 'naturally ordered to the good of spouses and the generation and education of children' (Catechism of the Catholic Church 2353). Homosexual acts thus 'do not proceed from a genuine affective and sexual complementarity. Under no circumstances can they be approved.' (Catechism of the Catholic Church 2357)

What the above analysis shows is that the continuity of the nation is believed to be ensured by means of endogenous biological reproduction, a myth that can be maintained only by naturalizing the patriarchal family and associated public and private roles of men and women. Gays and lesbians are thought to threaten the national narrative by undermining the patriarchal family underpinning the national community, failing to contribute to its biological and cultural reproduction, failing to adhere to national stereotypes of masculinity and femininity, confusing the traditional public and private roles of men and women, and deviating from its shared norms, especially those derived from religious teaching. ${ }^{14}$

\section{Hypotheses, data and methods}

Having identified the mechanism through which homosexuality is constructed as a threat to the nation, we now proceed to test the articulated relationship by formulating a hypothesis capturing our theory:

$\mathrm{H}_{1}$ : National and Catholic collective narcissism (whereby the in-group is defined in national and Catholic terms) should predict higher levels of homophobia.

As our theoretical discussion showed that people who hold collective narcissistic beliefs about the nation oppose homosexuality because they believe gays and lesbians (i) fail to adhere to traditional group norms on appropriate masculinity and femininity and (ii) threaten the biological and cultural reproduction of the nation, we developed a further hypothesis:

14 We acknowledge that 'traditional' is a floating signifier but we are using it here to reflect the patriarchal meaning attached to it by populists and nationalists. 
$\mathrm{H}_{2}$ : National and Catholic collective narcissism should predict homophobia via the belief that gender roles should be grounded in traditional national and religious values, which in turn predict a tendency to uphold traditional beliefs in gender roles, which therefore engenders the belief that homosexuality is a threat to the nation. In other words, the relationship between national and Catholic collective narcissism and homophobia should be sequentially explained by three mediators: the belief that gender roles should be grounded in national and religious values; the tendency to uphold the traditional beliefs about gender roles; and the belief homosexuality is a national threat.

To test these hypotheses, we carried out two studies. The first study sought to construct a model, establishing the predicted relationships between the variables, while the second sought to replicate it. For study 1, a representative sample of 543 Polish adults (56.2 per cent female/43.8 per cent male; $M_{\text {age }}=30.46 ; S D_{\text {age }}=15.19$; median age $=31$ ) was recruited by the Ariadna online research panel. ${ }^{15}$ As the aim of the research is to explain homophobic prejudice, only those participants who stated they were heterosexual were included in the analyses. ${ }^{16} \mathrm{~A}$ cumulative 20 per cent of the sample reported themselves to be very conservative, conservative or somewhat conservative, with 38 per cent of the sample placing themselves in the centre and the remaining 42 per cent on the liberal end of the spectrum.

We utilized multiple techniques from the broad structural equation modelling framework as our empirical strategy. In the first step, we employed a graded response model from item

15 See https://panelariadna.pl.

16 In Study 1 there were 23 respondents who defined their sexual orientation as homosexual, 20 who defined their sexual orientation as bisexual and 34 who chose not to disclose their sexual orientation. In Study 2 those numbers were 33, 34 and 42, respectively. We decided not to include these participants in the analyses as we could not reliably predict the effect of their non-normative (or unknown) sexual orientation and we could not reliably explore this possible effect, as the number of participants in each group was too small to warrant reliable intergroup comparisons with reference to our variables of interest. The inferences from our analyses should thus be limited to beliefs and attitudes of participants representing the heterosexual majority. 
response theory applications to improve the psychometric qualities of the measurements of all variables. This method treats the responses as ordinal categories and is instrumental in assessing the quality of individual items and the measurement as a whole. Next we used confirmatory factor analyses to identify the factors which correspond to the organizing latent variables, before turning to path analyses to test the hypotheses about the relationships between the variables. The Online Appendix elaborates on the psychometric qualities and the measurements models and provides descriptive statistics of the full scales.

We used measurements corresponding to six psychological constructs. We used Catholic and National Collective Narcissism as our independent variables (Golec de Zavala et al., 2009; Golec de Zavala \& Bierwiaczonek, 2020). (National Collective Narcissism sample item: 'If the Polish nation had a greater say in the world, the world would be a much better place.' Catholic Collective Narcissism sample item: 'The Catholic Church deserves special treatment.') As the separate National and Catholic Collective Narcissism scales were strongly positively correlated and made the same predictions, we merged the two into a higher-order scale and labelled it 'National Collective Narcissism'. This improved the power of collective narcissism to predict homophobia. The outcome variable in the model that measured explicit prejudice against homosexuals is the refined and shortened version of the Modern Homonegativity scale for homosexual men developed by Morrison and Morrison (2002). (Modern Homonegativity sample item: 'Gay men should stop complaining about the way they are treated in society and simply get on with their lives.')

We hypothesize three constructs mediating the relationship between national collective narcissism and explicit prejudice against homosexuals. The first is another higher-order construct that merges the belief in religious and national values as bases for the definition of gender roles in Poland. We labelled this construct 'Religious and National Beliefs about Gender Roles'. (Religious and National Beliefs about Gender Roles sample item: 'Women should 'respect themselves' for the good of the nation.') The second mediator reflects 'Traditional Beliefs about Gender Roles'; here we used the scale by Dasgupta \& Rivera (2006). (Traditional Beliefs about Gender Roles sample item: 'Men lose more than they gain from women's emancipation.') While the latter mediator defines traditional gender roles per se, the former specifies that gender roles are best defined by the nation and religion. The third mediator is the 'Homosexuality as a National Threat' belief, which measures the perception that 
homosexuality is a threat to the reproduction of the Polish nation. (Homosexuality as a National Threat sample item: 'By not having children, gays and lesbians threaten the continued existence of the nation.') Table I displays the descriptive statistics of the psychological constructs and Figure I shows the distributions (see Appendix). Further information about the measurement instruments, item wordings, etc., can be found in the Online Appendix.

Ethical approval for the research was provided by the Research Ethics Committee of UCL [3596/002] and the Scientific Research Ethics Commission of the University of Social Sciences and Humanities, Warsaw [53/2018].

\section{Study 1: Results}

The first model evaluates whether 'Religious and National Beliefs about Gender Roles', 'Traditional Beliefs about Gender Roles' and 'Homosexuality as a National Threat' sequentially mediate the relationship between 'National Collective Narcissism' and explicit prejudice towards homosexuals. All results are based upon 10,000 times resampled data; bias-adjusted bootstrapped confidence intervals and all coefficients are provided in the tables that follow the path diagrams. Note that, since we use a fully saturated model to test serial mediation (paths present between all variables), goodness-of-fit statistics are perfect and should not be interpreted, except the $\mathrm{R}^{2}$, which is the explained variance. Table II shows the goodness-offit statistics for the path model in Study 1.

The results reveal that the total effect of 'National Collective Narcissism' on 'Modern Homonegativity' is statistically significant $(\beta=0.488 ; 95 \% \mathrm{Cl}[0.473,0.646] ; z=12.739 ; p<.000)$. Those results are in line with Hypothesis 1 . In order to test the psychological mechanism underlying this association and test the theoretical model outlined by Hypothesis 2 we looked at the sequential indirect mediation of variables linking 'National Collective Narcissism' to 'Modern Homonegativity' The predicted relationship between 'National Collective Narcissism' and 'Religious and National Beliefs about Gender Roles' is significant $(\beta=0.76 ; 95 \% \mathrm{Cl}$ $[0.744,0.863], z=26.23 ; p<.001)$. The predicted relationships between the three mediators are all statistically significant, which enables the test for serial multiple mediation. The serial mediation that include all the mediators in the predicted order is significant $(\beta=0.063 ; 95 \%$ $\mathrm{Cl}[0.049,0.102] ; z=5.423 ; p<.000$, Figure I). Additionally, the sequential indirect path between 'National Collective Narcissism' and 'Modern Homonegativity', mediated by 'Religious 
and National Beliefs about Gender Roles' and 'Traditional Beliefs about Gender Roles' is also significant $(\beta=0.177 ; 95 \% \mathrm{Cl}[0.152,0.266] ; z=7.065 ; p<.000)$. The indirect path between 'National Collective Narcissism' and 'Modern Homonegativity' mediated by 'Religious and National Beliefs about Gender Roles' and 'Homosexuality as a National Threat' is also statistically significant $(\beta=0.454,95 \% \mathrm{Cl}[0.407,0.651] ; z=8.324 ; p<.000)$. Finally, after the previous direct and indirect effects are taken into account, the indirect path between 'National Collective Narcissism' and 'Modern Homonegativity', mediated by 'Religious and National Beliefs about Gender Roles' is negative and statistically significant $(\beta=-0.342 ; 95 \% \mathrm{Cl}[-0.533,-0.259$; $z=-5.581 ; p<.000)$. The model holds controlling for demographic predictors of homophobia identified in previous research: age, gender and political conservatism (Bouton et al. 1989). Total explained variance in explicit prejudice against homosexuals is 56 per cent. All coefficients are shown in Table III and Table IV (see Appendix). Those results are in line with Hypothesis 2 .

In Study 2, we aimed to replicate the results of Study 1 as the measurements used in Study 1 were constructed based on the data obtained in this study. We aimed to test the same hypotheses with measurements obtained from Study 1.

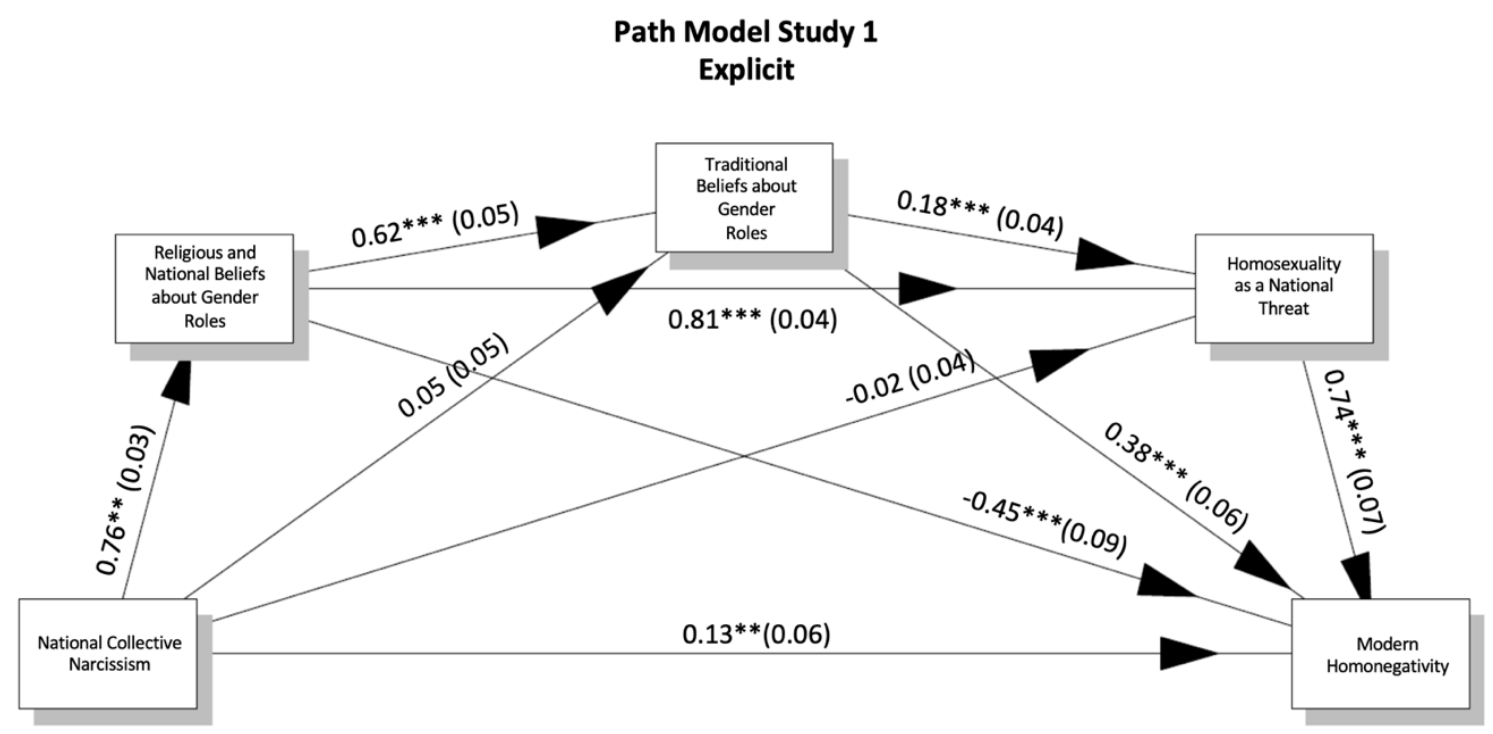

Figure II: Path diagram explaining explicit prejudice against homosexuals. Standardized coefficients are reported as path coefficients; standard error in parentheses; ${ }^{* *} p<0.01, * * *$ $p<0.001$. $R^{2}$ Modern Homonegativity $=0.555 ; R^{2}$ Homosexuality as a National Threat $=0.855 ; R^{2}$ Traditional Beliefs about Gender Roles $=0.431 ; R^{2}$ Religious and National Beliefs about Gender Roles $=0.577$ 


\section{Study 2: Methods}

We obtained data from an independent nationally representative sample of 879 Polish adults (47.5 per cent female/52.5 per cent male; $M_{\text {age }}=43.17 ; S D_{\text {age }}=13.59 ;$ median age $=42$ ) to test whether the results from Study 1 replicate. The data collection was supported by the Arianda online research panel as in Study 1. Only participants who stated they were heterosexual were included in the analyses. 22 per cent of the sample placed themselves on the conservative side of the political orientation spectrum, 36 per cent in the middle and 42 per cent reported that they were somewhat liberal, liberal or very liberal. We repeated the same measures and the methods employed in Study 1. Item-level descriptive statistics and the details of the measurement models can be found in the Online Appendix. Table VIII displays the descriptive statistics of the constructs. Table VI shows the goodness-of-fit statistics for the path model in Study 2. Figure III shows the distributions (see Appendix).

\section{Study 2: Results}

All the paths in the model are statistically significant; all the associations between 'National Collective Narcissism' and all the mediators are significant. The indirect path between 'National Collective Narcissism' and 'Modern Homonegativity', mediated by 'Religious and National Beliefs about Gender Roles' is negative and statistically significant ( $\beta=-0.178 ; 95 \% \mathrm{Cl}$ $[-0.292,-0.124 ; z=-4.820 ; p<.000)$. The indirect paths via 'Traditional Beliefs about Gender' $(\beta=0.066 ; 95 \% \mathrm{Cl}[0.043,0.117 ; z=4.009 ; p<.000)$ and 'National Homosexual Threat' $(\beta=$ $0.050 ; 95 \% \mathrm{Cl}[0.027,0.092 ; z=3.526 ; \mathrm{p}<.000)$ are also significant, and positive. The indirect path between 'National Collective Narcissism' and 'Modern Homonegativity', mediated by 'Religious and National Beliefs about Gender Roles' and 'Traditional Beliefs about Gender Roles' $^{\prime}$ is significant $(\beta=0.137 ; 95 \% \mathrm{Cl}[0.118,0.200] ; z=7.575 ; p<.000)$. The indirect path mediated by 'Religious and National Beliefs about Gender Roles' and 'Traditional Beliefs about Gender Roles' significant $(\beta=0.177,95 \% \mathrm{Cl}[0.152,0.266] ; z=7.065 ; p<.000)$. The same is true for the other indirect paths that include two mediators: 'Religious and National Beliefs about Gender Roles + Homosexuality as National Threat' ( $\beta=0.203 ; 95 \% \mathrm{Cl}[0.173,0.301]$; z $=7.176 ; p<.000)$ and 'Traditional Beliefs about Gender + National Homosexual Threat' $(\beta=$ $0.025 ; 95 \% \mathrm{Cl}[0.017,0.045] ; z=4.120 ; p<.000)$. Finally, the indirect path with all the three mediators is also significant $(\beta=0.052 ; 95 \% \mathrm{Cl}[0.043,0.081] ; z=6.307 ; p<.000)$. The total 
effect of 'National Collective Narcissism' on 'Modern Homonegativity' is significant ( $\beta=0.535$; $95 \% \mathrm{Cl}[0.545,0.683] ; z=17.311 ; p<.000)$, which is in line with Hypothesis 1 . All the indirect effects and the serial mediations are statistically significant. All predictors explain $51 \%$ of the variation in explicit prejudice against homosexuals. The model holds controlling for demographic predictors of homophobia identified in previous research: age, gender and political conservatism (Bouton et al. 1989). Tables VII and VIII include all the coefficients (see Appendix).

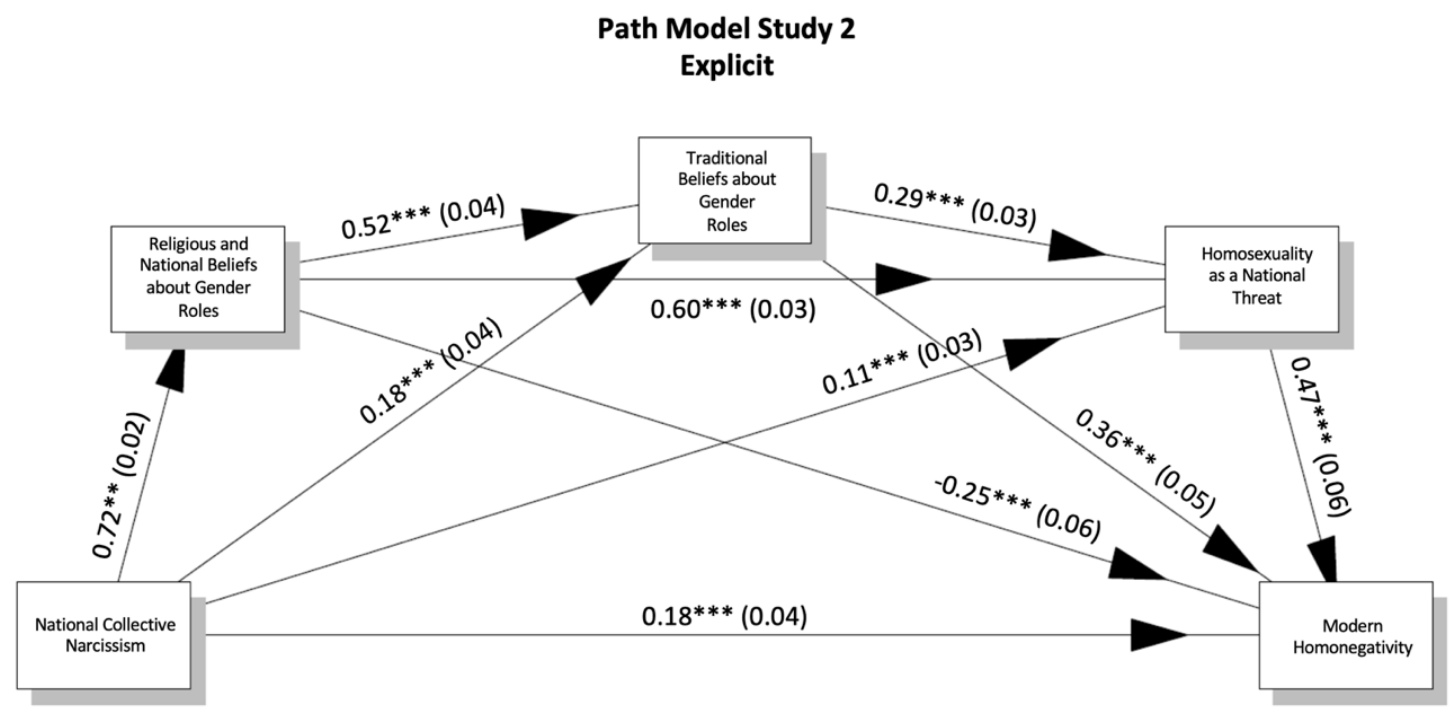

Figure IV: Path diagram explaining explicit prejudice against homosexuals. Standardized coefficients are reported as path coefficients; standard error in parentheses; $p<0.01, * * *$. $\mathrm{R}^{2}$ Modern Homonegativity $=0.509 ; \mathrm{R}^{2}$ Homosexuality as a National Threat $=0.812 ; \mathrm{R}^{2}$ Traditional Beliefs about Gender Roles $=$ $0.444 ; R^{2}$ Religious and National Beliefs about Gender Roles $=0.542$

\section{Discussion}

The increased visibility of LGBT people in Poland since the collapse of communism has been met with a counter-reaction in the form of homophobic rhetoric and violence, with various surveys confirming that attitudes towards sexual minorities in Poland are among the worst in the EU. Intolerance towards sexual minorities cannot be explained with reference to a single factor but is the cumulative effect of a range of social influences. Nevertheless, numerous studies have shown that homosexuality in Central and Eastern Europe, including Poland, is particularly reviled because it is constructed as a threat to the continued existence of the 
nation and the core values defining national identity - particularly those derived from religion. However, these studies tend to focus on attempts by right-wing politicians to justify their homophobic rhetoric and attempts to marginalize LGBT citizens in the name of religion and nationality but without examining whether nationalist beliefs can predict homophobia at the level of individual beliefs. Nor do they take account of the emergence of right-wing populism in the region, whereby populists have sought to redefine membership of the nation in nativist terms, justifying it by national collective narcissism. This article seeks to address these omissions.

While ours is not the first study to seek to explain homophobia with reference to nationalism, we argue that the latter concept is too broad to explain why attitudes towards gays and lesbians should be related to people's beliefs about their nation. We also argue that not all positive beliefs about a nation are related to homophobia. For this reason, we have sought to provide greater nuance by introducing the concept of 'national collective narcissism' (the belief that one's own nation is exceptional and entitled to privileged treatment but it is not sufficiently recognized by others). As homophobic rhetoric and violence have spiked since rightwing populism came to dominate Polish politics and as right-wing populists promote a nativist understanding of the nation, appealing to those who feel left behind by globalization and cultural change, we argue that, in the contemporary Polish context, national collective narcissism merged with Catholic collective narcissism is the most precise conceptualization of the belief about national identity that underlies homophobia. We therefore selected 'National Collective Narcissism' as our predictor.

Given that Catholic religiosity defines the content of national identity popularized by rightwing populists in Poland, we assessed Catholic collective narcissism as well as national collective narcissism. As expected, our analysis showed that Catholic and national collective narcissism overlap almost entirely in their prediction of homophobia and beliefs leading to homophobia in Poland. This suggests that 'Catholic' and 'Polish' grandiosity have become fused in the minds of the respondents who scored high on both collective narcissism scales. From this we can infer that self-righteous but threatened Catholicism has become central in defining what it means to be Polish among these respondents. Given the antipathy of the Catholic Church, in general, and Polish bishops, in particular, towards sexual minorities, and given the power of the Catholic Church to define family, marriage and appropriate gender norms, the 
conflation of Polish and Catholic inevitably constructs individuals not adhering to Catholic principles of morality and behaviour, such as non-heterosexuals, as 'not real Poles'. This then legitimizes attempts by nationalist and populist politicians to cast gay and lesbian Poles as less deserving of full citizenship and, in extreme cases, as enemies of Poland.

To explain the relationship between national collective narcissism and homophobia, we explored the theoretical literature on the relationship between the beliefs about the nation and homosexuality. Previous research has identified various threats that homosexuals are believed to pose to the nation and could therefore explain homophobia: namely, non-heterosexuals threaten the biological and cultural reproduction of the nation; fail to adhere to stereotypes of masculinity and femininity; confuse the traditional public and private roles of men and women; and deviate from the nation's shared norms, especially those derived from religious teaching. 'Homosexuality as a National Threat' was thus chosen as the first intervening variable between collective narcissism and homophobia. Given the factors mediating the relationship between the nation and homosexuality in the literature relate primarily to gender roles, we selected 'Traditional Beliefs about Gender Roles' and 'Religious and National Beliefs about Gender Roles' as two further intervening variables.

In Study 1 we established the basic relationship between collective narcissism and explicit homophobia via the three mediating variables. In Study 2 we replicated the study, with different respondents, to test the validity of the model. Supporting our hypothesis, our analysis shows that the total effect of 'National Collective Narcissism' on explicit homophobia in both studies was statistically significant. Thus, in Poland, homophobia could be explained with reference to our respondents' national and religious collective narcissism. Our studies explored this association further, determining the underlying psychological mechanism. It consists of beliefs associated with national and religious collective narcissism with reference to gender and sexuality. Most immediately, religious and national collective narcissism engenders support for traditional religious teaching on those issues which resulted in traditional gender beliefs and a more specific belief that homosexuality is a threat to national identity. Most of the results were consistent between the two studies, especially the results in line with the tested hypotheses. One finding was not consistent. The associations between 'National Collective Narcissism' and 'Religious and National Beliefs about Gender Roles' was significant in a larger 
sample in Study 2 but did not reach the conventional level of statistical significance (although it was in the predicted direction) in the smaller Study 1.

From this we can conclude that the threat that homosexuals are believed to pose to the Polish nation relates primarily to the perception that they undermine traditional gender roles - defined by the Church for the good of the nation - rather than the threat that they are believed to pose to the nation's reproduction. In other post-communist states, such Latvia, the presence of large ethnic minorities gave rise to fears that their physical nations were at risk of dying out, allowing right-wing politicians to attack gays and lesbians for failing to have children and thereby ensure the continued existence of the nation (Mole 2011: 551). The high degree of ethnic homogeneity in Poland makes it more difficult for such fears to take hold there. Rather than being seen as a threat to the physical nation, homosexuality in Poland is understood as a threat to the patriarchal gender order underpinning the Polish nation. In the Polish context, the implications of this finding are particularly worrying in view of the 'gender ideology' discourse being propagated by the Catholic Church and right-wing social and political actors (see Graff and Koroloczuk 2017); any attempts to define gender and sexuality outside the narrow confines of patriarchal heteronormativity are constructed as a deliberate attack on the traditional Polish family, as Jarosław Kaczyński has repeatedly confirmed. At a PiS rally in the run-up to the 2019 European Parliament elections, when discussing the 'threat' posed by the LGBT Declaration signed by Rafał Trzaskowski, the liberal Mayor of Warsaw, Kaczyński declared:

This threat is an attack on the family. [...] At all times the natural identities of boys and girls are to be questioned. The whole mechanism of preparing children for the future roles of mother and father is to be destroyed. (Gernand 2019)

Given the strength of populism across Europe, our findings about Poland could help to explain homophobia in other contexts, providing a means to identify the specific aspects of the nation that homosexuality is believed to threaten: religious values, gender norms, reproduction or a combination of the three. (This would, of course, require further research on individual case studies.) Our finding about the fusion of national and religious collective narcissism in Poland 
can also help explain why homophobia is higher in Catholic countries of Eastern Europe where Catholicism is a core national value, such as Lithuania, than in others, such as Slovenia.

An additional future line of research would be to capitalize on the distinction between national collective narcissism and national in-group satisfaction (Golec de Zavala et al., 2019) to better understand how beliefs about the same nation can predict different attitudes towards sexual minorities. National in-group satisfaction is a positive evaluation of the nation without narcissistic grandiosity and resentment. It is associated with intergroup tolerance and lower prejudice (Golec de Zavala \& Lantos, 2020). This presents a testable possibility that national in-group satisfaction and national collective narcissism predict opposite attitudes towards homosexuals. This also suggests that emphasizing the importance of positive national satisfaction and deemphasizing national collective narcissism in the definition of Polish national identity may offer a route towards reduction of homophobia in Poland.

In line with the research of Ayoub and Chetaille (2020), LGBT activists could use findings produced using our approach to frame their claims accordingly. In the Polish context, for example, our finding that homosexuality is understood as a threat to the gender order underpinning the Polish nation rather than to its biological reproduction (as is the case elsewhere in Europe) could then be used by activists to frame Polish gays and lesbians as sharing the same values as heterosexual men and women in terms of 'willpower, honour, courage' (Nagel 1998: 245) and inculcating in children Polish language and culture, respectively.

The need for LGBT activists to continually refine their strategies is essential. As scapegoating LGBT people has proved to be a successful electoral strategy, the instrumentalisation of homophobia by populists in Poland and many other European countries is unlikely to disappear any time soon.

\section{Acknowledgments}

This project was funded by the Noble Foundation's Programme on Modern Poland (http://pomp.com.pl/en). The project ran from September 2018 to October 2019.

We would also like to thank the two anonymous reviewers for their extremely constructive feedback and suggestions for improving our article. 


\section{References}

Adorno T. (1997). Gesammelte Schriften in zwanzig Bänden [Collected writings in 20 volumes]. Berlin: Suhrkamp/Insel.

Adorno TW, Frenkel-Brunswik E, Levinson DJ and Sanford RN (1950) The Authoritarian Personality. New York: Harper \& Row.

Anderson B (1983) Imagined Communities: Reflections on the Origin and Spread of Nationalism. London: Verso.

Ayoub PM (2014) With arms wide shut: threat perception, norm reception, and mobilized resistance to LGBT rights. Journal of Human Rights, 13: 337-362.

Ayoub PM (2016) When States Come Out. Europe's Sexual Minorities and the Politics of Visibility. Cambridge: Cambridge University Press.

Ayoub PM and Chetaille A (2020) Movement/countermovement interaction and instrumental framing in a multi-level world: rooting Polish lesbian and gay activism. Social Movement Studies, 19: 21-37.

Barrington LW (1997) "Nation" and "Nationalism": The misuse of key concepts in Political Science. PS: Political Science and Politics, 30: 712-716

Bouton RA, Gallaher PE, Garlinghouse PA, Leal T, Rosenstein LD and Young RK (1989) Demographic variables associated with fear of AIDS and homophobia. Journal of Applied Social Psychology, 19: 885-901.

Brubaker R and Cooper F (2000) Beyond "identity". Theory and Society 29, 1-47.

Catechism of the Catholic Church. (n.d.) Available at: www.vatican.va/archive/ENG0015/_INDEX.HTM.

Charles N, Hintjens H (1998) Gender, Ethnicity and Political Ideologies. London: Routledge.

Cichocka A and Cislak A (2020) Nationalism as collective narcissism. Current Opinion in Behavioral Sciences, 34: 69-74.

Dasgupta N, Rivera LM (2006) From automatic antigay prejudice to behavior: The moderating role of conscious beliefs about gender and behavioral control. Journal of Personality and Social Psychology, 91: 268-280.

Ebert M (2005) The Catholic Church and Poland's Accession to the European Union. In: Drew J (ed.) Redefining Europe. Amsterdam, New York: Rodopi, 165-180. 
Eurobarometer on Discrimination 2015: Social Acceptance and Perceptions of Discrimination on the Grounds of Sexual Orientation and Gender Identity (2016) Available at: ec.europa.eu/newsroom/document.cfm?doc_id=47636.

European Parliament (2007) European Parliament Resolution of 26 April 2007 on Homophobia in Europe, 26 April 2007, P6_TA(2007)0167. Available: www.europarl.europa.eu/sides/getDoc.do?pubRef=-//EP//TEXT+TA+P6-TA-20070167+0+DOC+XML+V0//EN.

Federico C, Golec de Zavala A, Baran T (2021) Collective narcissism as a Basis for Nationalism [Under review]

Fox JE and Idriss-Miller C (2002) Everyday nationhood. Ethnicities 8, 536-576.

Fromm E (1964) The Heart of Man: Its Genius for Good and Evil. New York: Harper and Row. Gellner E (1983) Nations and Nationalism. Cambridge: Cambridge University Press.

Gernand A (2019) Wybory do europarlamentu 2019. Jarosław Kaczyński na Podkarpaciu: Nasi przeciwnicy atakują dzieci. [2019 European Parliament Elections. Jarosław Kaczyński in Podkarpacie. Our opponents are attacking children.] wyborcza.pl, 9 March. Available at: http://rzeszow.wyborcza.pl/rzeszow/7,34962,24532361,jaroslaw-kaczynski-na- podkarpaciu-o-ataku-przeciwnikow-pis-na.html. Accessed: 31 December 2019.

Golec de Zavala, A., Bierwiaczonek, K. (2020). Male, National, and Religious Collective Narcissism Predict Sexism. Sex Roles. [Early View: https://doi.org/10.1007/s11199-02001193-31

Golec de Zavala A, Cichocka A, Eidelson R, Jayawickreme N (2009) Collective narcissism and its social consequences. Journal of Personality and Social Psychology, 97: 1074-1096.

Golec de Zavala A, Dyduch-Hazar K, Lantos D (2019) Collective Narcissism: Political Consequences of Investing Self- Worth in the Ingroup's Image. Advances in Political Psychology, 40: $37-74$.

Golec de Zavala A, Lantos D (2020) Collective Narcissism and Its Social Consequences: The Bad and the Ugly. Current Directions in Psychological Science 29, 273-278.

Golec de Zavala A, Lantos D and Keenan O (2021) Collective narcissism and the motivational underpinning of the populist backlash. In: Forgas J, Crano W and Fiedler K (Eds) The Psychology of Populism. Oxon: Taylor \& Francis, 105-122. 
Golec de Zavala A, Keenan O (2019) Collective narcissism as a framework for understanding the appeal of right-wing populism. Journal of Theoretical Social Psychology. [Early View: https://doi.org/10.1002/jts5.69]

Graff A (2010) Looking at pictures of gay men: political uses of homophobia in contemporary Poland. Public Culture 22: 583-603.

Graff A and Korolczuk E (2017) "Worse than communism and nazism put together": War on Gender in Poland. In: Paternotte D, Kuhar R (eds) Anti-Gender Campaigns in Europe: Mobilizing against Equality. London: Rowman and Littlefield, 175-194.

Górska P and Mikołajczak M (2015) Tradycyjne i nowoczesne uprzedzenia wobec osób homoseksualnych w Polsce [Traditional and contemporary prejudice towards homosexuals in Poland]. In: Stefaniak A, Bilewicz M and Winiewski M (eds) Uprzedzenia w Polsce [Prejudice in Poland]. Warszawa: Liberi Libri, 171-198.

Hall D (2015) Antagonism in the making: religion and homosexuality in post-communist Poland. In: Sremac S, Ganzevoort RR (eds) Religious and Sexual Nationalisms in Central and Eastern Europe. Gods, Gays and Governments. Leiden: Brill, 74-92.

Healey D (2001) Homosexual Desire in Revolutionary Russia: The Regulation of Sexual and Gender Dissent. London: University of Chicago Press.

Herek GM, Glunt EK (1988) An epidemic of stigma: public relations to AIDS. American Psychologist, 43(11): 886-891.

Herek GM (1986) On heterosexual masculinity: some psychical consequences of the social construction of gender and sexuality. American Behavioural Scientist 29: 563-577.

Inglehart R, Baker WE (2000) Modernization, cultural change, and the persistence of traditional values. American Sociological Review, 65: 19-51.

Inglehart R, Norris P (2016) Trump, Brexit, and the Rise of Populism: Economic Have-Nots and Cultural Backlash. SSRN Electronic Journal. Available online: https://doi.org/10.2139/ssrn.2818659

John T and Darwish M (2019) Polish city holds first LGBTQ pride parade despite far-right violence. CNN, 21 July. Available at: https://edition.cnn.com/2019/07/21/europe/bialystokpolish-lgbtq-pride-intl/index.html.

Kliszyński K (2001) A child of a young democracy: the Polish gay movement, 1989-1999. In: Flam H (ed.) Pink, Purple, Green: Women's, Religious, Environmental and Gay/Lesbian Movements in Central Europe Today. New York: Columbia University Press: 161-168. 
Kosterman R. and Feshbach S (1989) Toward a measure of patriotic and nationalistic attitudes. Political Psychology, 10, 257-274.

Mole RCM. (2011) Nationality and sexuality: homophobic discourse and the 'national threat' in contemporary Latvia. Nations and Nationalism 17, 540-560.

Mole RCM (2016) Nationalism and homophobia in Central and Eastern Europe. In: Slootmaekers K, Touquet H, Vermeersch P (eds) EU Enlargement and Lesbian and Gay Politics: The Impact of Eastern Enlargement on Rights, Activism and Prejudice. Basingstoke: Palgrave Macmillan: 99-121.

Morrison MA, Morrison TG (2002) Development and validation of a scale measuring modern prejudice toward gay men and lesbian women. Journal of Homosexuality, 43: 15-37.

Mosse GL (1985) Nationalism and Sexuality: Respectability and Abnormal Sexuality in Modern Europe. New York: Howard Fertig.

Mosse, GL (1996) The Image of Man: The Creation of Modern Masculinity. Oxford: Oxford University Press.

Mozaika (2007) Homophobic Speech in Latvia: Monitoring the Politicians. Available at: www.ilga-europe.org/home/what_we_do/ilga_europe_as_a_funder/completed_projects/homophobic_hate_speech_in_latvia_monitoring_the_decision_makersi.

Mudde, C, Rovira Kaltwasser, C (2017) Populism. A Very Short Introduction. Oxford: Oxford University Press.

n.a. (2019) Party Leader Calls LGBT Rights an Imported Threat to Poland. Voice of America, 25 April. Available at: www.voanews.com/europe/party-leader-calls-lgbt-rights-imported-threat-poland.

Nachescu V (2005) Hierarchies of difference: national identity, gay and lesbian rights and the Church in post-communist Romania. In: Stulhofer A, Sandford T (eds) Sexuality and Gender in Post-Communist Eastern Europe and Russia. New York and London: Haworth Press: $57-78$

Nagel J (1998) Masculinity and Nationalism: Gender and Sexuality in the Making of Nations. Ethnic and Racial Studies, 21: 242-269

Nagel J (2000) Ethnicity and sexuality. Annual Review of Sociology, 26: 107-33.

Nagel J (2003) Race, Ethnicity and Sexuality. Intimate Intersections, Forbidden Frontiers. Oxford: Oxford University Press. 
Novikova I (2002) Gender, ethnicity and identity politics in Latvia. In: Ivekovic R, Mostov J. (eds) From Gender to Nation. Ravenna: Longo Editore, 171-187.

O’Dwyer C, Vermeersch P (2016) 'From Pride to Politics: Niche-Party Politics and LGBT Rights in Poland'. In: Slootmaekers K, Touquet H, Vermeersch P (eds) EU Enlargement and Lesbian and Gay Politics: The Impact of Eastern Enlargement on Rights, Activism and Prejudice. Basingstoke: Palgrave Macmillan: 123-145

Plugge-Foust, C, Strickland, G (2000) Homophobia, Irrationality, and Christian Ideology: Does a Relationship Exist? Journal of Sex Education and Therapy, 25: 240-244.

Puar JK (2007) Terrorist Assemblages: Homonationalism in Queer Times. Durham, NC: Duke University Press.

Pryke S (1998) Nationalism and sexuality, what are the issues? Nations and Nationalism, 4: 529-546.

Rowatt WC, LaBouff J, Johnson M, Froese P, Tsang J-A (2009) Associations among religiousness, social attitudes, and prejudice in a national random sample of American adults. Psychology of Religion and Spirituality, 1: 14-24.

Salmela M, von Scheve C (2017) Emotional roots of right-wing political populism. Social Science Information, 56: 567-595.

Schatz RT, Straub E and Lavine H (1999) On the varieties of national attachment: Blind versus constructive patriotism. Political Psychology, 20, 151-174.

Smith AD (1986) The Ethnic Origin of Nations. Oxford: Blackwell.

Szczerbiak A (2007) 'Social Poland' Defeats 'Liberal Poland'? The September-October 2005 Polish Parliamentary and Presidential Elections. Journal of Communist Studies and Transition Politics, 23: 203-232

Selinger M (2008) Intolerance towards Gays and Lesbians in Poland. Human Rights Review, 9: 15-27.

Slootmaeckers K (2019) Nationalism as competing masculinities: homophobia as a technology of othering for hetero- and homonationalism. Theory and Society 48, 239-265.

Štulhofer A, Sandfort T. eds. (2005) Sexuality and Gender in Post-Communist Eastern Europe and Russia. New York: Haworth Press.

Tomasik K (2012) Gejerel. Mnieszości Seksualne w PRL-u. Warszawa: Krytyka Polityczna. Watson P (1993) Eastern Europe's silent revolution: gender. Sociology, 27: 471-87. 
Weeks J (1992) Foreword. In: Schmitt A, Sofer J (eds) Sexuality and Eroticism among Males in Moslem Societies. New York: Haworth Press, ix-xii.

Whitley B (2009) Religiosity and attitudes towards lesbians and gay men: a meta-analysis. International Journal for the Psychology of Religion, 19: 21-38.

Yuval-Davis N (1996) Gender and Nation. London: Sage. 
Appendix: Tables and figures

Table I: Descriptive statistics of constructs used in Study 1

\begin{tabular}{llllllll}
\hline Abbreviation & Construct & Mean & SD & Median & Range & Skew & Kurtosis \\
\hline gCN & National Collective Narcissism & 0.41 & 0.22 & 0.41 & $0-1$ & 0.27 & -0.39 \\
hoGR & Religious and National Beliefs about Gender Roles & 0.31 & 0.23 & 0.29 & $0-1$ & 0.41 & -0.69 \\
nHT & Homosexuality as National Threat & 0.36 & 0.27 & 0.36 & $0-1$ & 0.35 & -0.9 \\
tBG & Traditional Beliefs about Gender Roles & 0.53 & 0.19 & 0.54 & $0-1$ & -0.15 & -0.15 \\
MHN & Modern Homonegativity & 0.63 & 0.25 & 0.63 & $0-1$ & -0.37 & -0.45 \\
\hline
\end{tabular}

All constructs are normalized factor scores. See Online Appendix for the measurement models and psychometric quality. 
Figure I: Distribution of constructs used in the analysis in Study 1

Density plot of normalized factor scores

Study 1

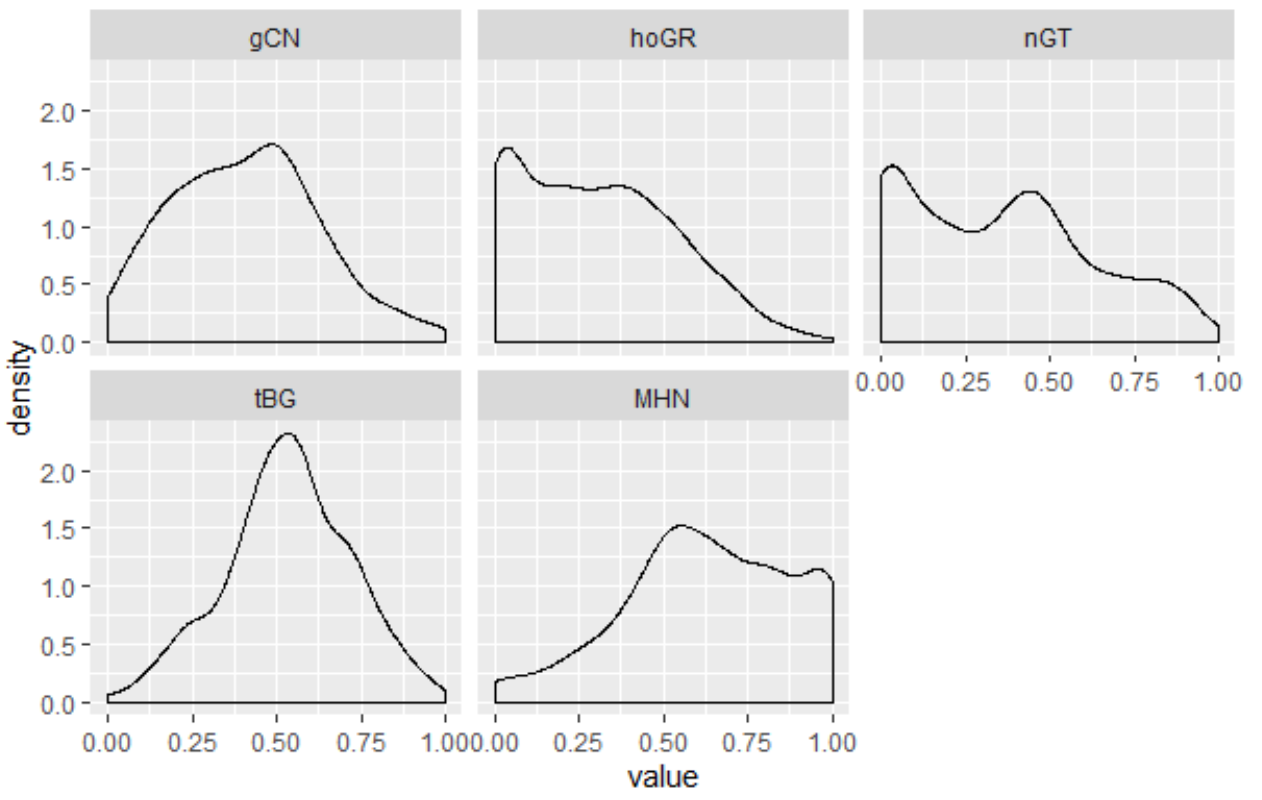

Table II: Goodness-of-fit statistics for path model Study 1

\begin{tabular}{|l|l|}
\hline Robust X2 (df): & $0^{* * *}(14)$ \\
\hline Robust CFI: & 1 \\
\hline Robust TLI: & 1 \\
\hline Robust RMSEA (P-value) $\mathbf{9 0} \% \mathbf{C l :}$ & 0 \\
\hline SRMR: & 0 \\
\hline
\end{tabular}


Table III: Coefficients in the path model explaining the explicit prejudice against homosexuals in Study 1.

\begin{tabular}{|c|c|c|c|c|c|c|c|}
\hline Path & est & se & $\mathbf{z}$ & pvalue & ci.lower & ci. upper & $\boldsymbol{\beta}$ \\
\hline $\begin{array}{l}\text { Religious and National Beliefs about Gender Roles } \rightarrow \text { Modern Ho- } \\
\text { monegativity }\end{array}$ & -0.49 & 0.09 & -5.68 & $<0.001$ & -0.652 & -0.325 & -0.45 \\
\hline Traditional Beliefs about Gender Roles $\rightarrow$ Modern Homonegativity & 0.51 & 0.06 & 8.28 & $<0.001$ & 0.387 & 0.624 & 0.38 \\
\hline Homosexuality as a National Threat $\rightarrow$ Modern Homonegativity & 0.67 & 0.07 & 9.81 & $<0.001$ & 0.540 & 0.809 & 0.74 \\
\hline National Collective Narcissism $\rightarrow$ Modern Homonegativity & 0.15 & 0.06 & 2.60 & 0.009 & 0.040 & 0.255 & 0.13 \\
\hline National Collective Narcissism $\rightarrow$ Higher-Order Gender Roles & 0.80 & 0.03 & 26.23 & $<0.001$ & 0.744 & 0.863 & 0.76 \\
\hline National Collective Narcissism $\rightarrow$ Traditional Beliefs about Gender & 0.04 & 0.05 & 0.81 & 0.416 & -0.051 & 0.142 & 0.05 \\
\hline $\begin{array}{l}\text { Religious and National Beliefs about Gender Roles } \rightarrow \text { Traditional Be- } \\
\text { liefs about Gender Roles }\end{array}$ & 0.50 & 0.05 & 10.82 & $<0.001$ & 0.408 & 0.588 & 0.62 \\
\hline National Collective Narcissism $\rightarrow$ Homosexuality as National Threat & -0.02 & 0.04 & -0.66 & 0.509 & -0.094 & 0.049 & -0.02 \\
\hline $\begin{array}{l}\text { Traditional Beliefs about Gender Roles } \rightarrow \text { Homosexuality as National } \\
\text { Threat }\end{array}$ & 0.27 & 0.04 & 7.59 & $<0.001$ & 0.198 & 0.336 & 0.18 \\
\hline $\begin{array}{l}\text { Religious and National Beliefs about Gender Roles } \rightarrow \text { Homosexuality } \\
\text { as National Threat }\end{array}$ & 0.96 & 0.04 & 26.93 & $<0.001$ & 0.894 & 1.035 & 0.81 \\
\hline
\end{tabular}


Table IV: Coefficients from the mediation analysis: explicit prejudice against homosexuals.

\begin{tabular}{|c|c|c|c|c|c|c|c|c|}
\hline Path & Mediator(s) & est & se & $\mathbf{z}$ & pvalue & ci.lower & ci.upper & $\beta$ \\
\hline \multirow{7}{*}{$\begin{array}{l}\text { National Collective } \\
\text { Narcissism } \\
\rightarrow \text { Modern Homonega- } \\
\text { tivity }\end{array}$} & $\begin{array}{l}\text { Religious and National Beliefs about } \\
\text { Gender Roles }\end{array}$ & -0.394 & 0.071 & -5.581 & 0.000 & -0.533 & -0.259 & -0.342 \\
\hline & Traditional Beliefs about Gender Roles & 0.021 & 0.026 & 0.806 & 0.420 & -0.024 & 0.077 & 0.018 \\
\hline & Homosexuality as National Threat & -0.016 & 0.025 & -0.649 & 0.516 & -0.066 & 0.033 & -0.014 \\
\hline & $\begin{array}{l}\text { Religious and National Beliefs about } \\
\text { Gender Roles + } \\
\text { Traditional Beliefs about Gender Roles }\end{array}$ & 0.204 & 0.029 & 7.065 & 0.000 & 0.152 & 0.266 & 0.177 \\
\hline & $\begin{array}{l}\text { Religious and National Beliefs about } \\
\qquad \text { Gender Roles + } \\
\text { Homosexuality as National Threat }\end{array}$ & 0.522 & 0.063 & 8.324 & 0.000 & 0.407 & 0.651 & 0.454 \\
\hline & $\begin{array}{l}\text { Traditional Beliefs about Gender Roles } \\
\qquad+ \\
\text { Homosexuality as National Threat }\end{array}$ & 0.007 & 0.009 & 0.833 & 0.405 & -0.009 & 0.026 & 0.006 \\
\hline & $\begin{array}{l}\text { Religious and National Beliefs about } \\
\text { Gender Roles + Traditional Beliefs } \\
\text { about Gender Roles + } \\
\text { Homosexuality as National Threat }\end{array}$ & 0.072 & 0.013 & 5.423 & 0.000 & 0.049 & 0.102 & 0.063 \\
\hline Total & & 0.562 & 0.044 & 12.739 & 0.000 & 0.473 & 0.646 & 0.488 \\
\hline
\end{tabular}


Table V: Descriptive statistics of the constructs used in Study 2

\begin{tabular}{|c|c|c|c|c|c|c|c|}
\hline $\begin{array}{l}\text { Abbrevia- } \\
\text { tion }\end{array}$ & Construct & Mean & SD & Median & Range & Skew & Kurtosis \\
\hline gCN & National Collective Narcissism & 0.41 & 0.23 & 0.40 & $0-1$ & 0.25 & -0.47 \\
\hline hoGR & Religious and National Beliefs about Gender Roles & 0.25 & 0.21 & 0.21 & $0-1$ & 0.77 & -0.01 \\
\hline nGT & Homosexuality as National Threat & 0.33 & 0.26 & 0.31 & $0-1$ & 0.48 & -0.66 \\
\hline tBG & Traditional Beliefs about Gender Roles & 0.55 & 0.21 & 0.56 & $0-1$ & -0.41 & 0 \\
\hline $\mathrm{MHN}$ & Modern Homonegativity & 0.63 & 0.26 & 0.63 & $0-1$ & -0.4 & -0.51 \\
\hline
\end{tabular}

Table VI: Goodness of fit statistics for path model Study 2

\begin{tabular}{|l|l|}
\hline Robust X2 (df): & $0^{* * *}(14)$ \\
\hline Robust CFI: & 1 \\
\hline Robust TLI: & 1 \\
\hline Robust RMSEA (P-value) $\mathbf{9 0} \% \mathbf{C l}:$ & 0 \\
\hline SRMR: & 0 \\
\hline
\end{tabular}


Figure III: Distribution of constructs used in the analysis in Study 2

Density plot of normalized factor scores

Study 2

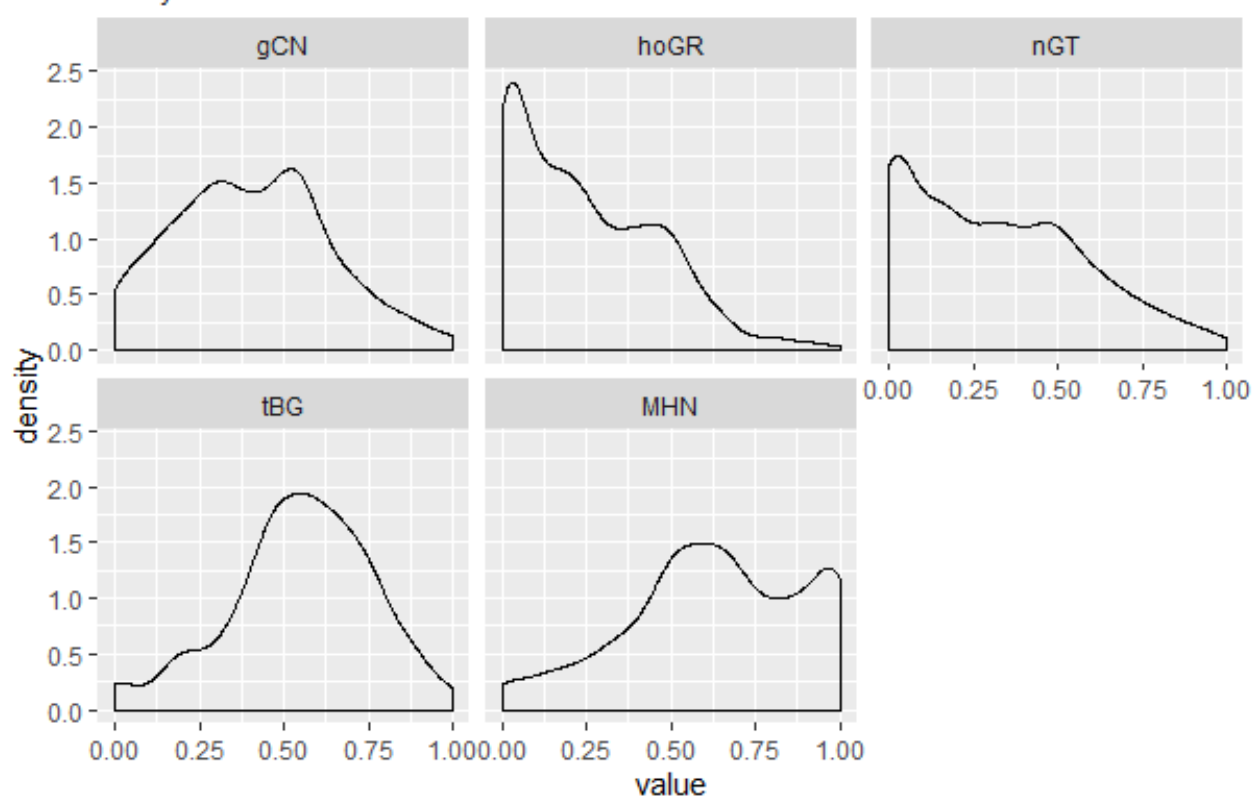


Table VII: Coefficients in the path model explaining the explicit prejudice against homosexuals in Study 2

\begin{tabular}{|c|c|c|c|c|c|c|c|}
\hline Path & est & se & $\mathbf{z}$ & pvalue & ci.lower & ci.upper & $\beta$ \\
\hline Religious/National Beliefs about Gender $\rightarrow$ Modern Homonegativity & -0.31 & 0.06 & -4.97 & $<0.001$ & -0.430 & -0.187 & -0.25 \\
\hline Traditional Beliefs about Gender $\rightarrow$ Modern Homonegativity & 0.45 & 0.05 & 8.68 & $<0.001$ & 0.347 & 0.551 & 0.36 \\
\hline National Homosexual Threat $\rightarrow$ Modern Homonegativity & 0.48 & 0.06 & 8.34 & $<0.001$ & 0.367 & 0.592 & 0.47 \\
\hline National Collective Narcissism $\rightarrow$ Modern Homonegativity & 0.21 & 0.04 & 4.72 & $<0.001$ & 0.120 & 0.291 & 0.18 \\
\hline National Collective Narcissism $\rightarrow$ Religious/National Beliefs about Gender & 0.67 & 0.02 & 28.79 & $<0.001$ & 0.623 & 0.714 & 0.72 \\
\hline National Collective Narcissism $\rightarrow$ Traditional Beliefs about Gender & 0.17 & 0.04 & 4.72 & $<0.001$ & 0.099 & 0.238 & 0.18 \\
\hline Religious/National Beliefs about Gender $\rightarrow$ Traditional Beliefs about Gender & 0.52 & 0.04 & 14.77 & $<0.001$ & 0.451 & 0.589 & 0.52 \\
\hline National Collective Narcissism $\rightarrow$ National Homosexual Threat & 0.12 & 0.03 & 3.75 & $<0.001$ & 0.056 & 0.181 & 0.11 \\
\hline Traditional Beliefs about Gender $\rightarrow$ National Homosexual Threat & 0.36 & 0.03 & 12.07 & $<0.001$ & 0.302 & 0.419 & 0.29 \\
\hline Religious/National Beliefs about Gender $\rightarrow$ National Homosexual Threat & 0.73 & 0.03 & 22.71 & $<0.001$ & 0.666 & 0.792 & 0.60 \\
\hline
\end{tabular}


Table VIII: Coefficients from the mediation analysis: explicit prejudice against homosexuals.

\begin{tabular}{|c|c|c|c|c|c|c|c|c|}
\hline path & mediator(s) & est & se & $\mathbf{z}$ & pvalue & ci.lower & ci.upper & $\beta$ \\
\hline \multirow{7}{*}{$\begin{array}{l}\text { National Collective } \\
\text { Narcissism } \\
\rightarrow \text { Modern Homo } \\
\text { Negativity }\end{array}$} & $\begin{array}{c}\text { Religious/National Beliefs about } \\
\text { Gender }\end{array}$ & -0.204 & 0.042 & -4.820 & 0.000 & -0.292 & -0.124 & -0.178 \\
\hline & Traditional Beliefs about Gender & 0.076 & 0.019 & 4.009 & 0.000 & 0.043 & 0.117 & 0.066 \\
\hline & National Homosexual Threat & 0.057 & 0.016 & 3.526 & 0.000 & 0.027 & 0.092 & 0.050 \\
\hline & $\begin{array}{l}\text { Religious/National Beliefs about } \\
\qquad \text { Gender }+ \\
\text { Traditional Beliefs about Gender }\end{array}$ & 0.157 & 0.021 & 7.575 & 0.000 & 0.118 & 0.200 & 0.137 \\
\hline & $\begin{array}{l}\text { Religious/National Beliefs about } \\
\text { Gender }+ \\
\text { National Homosexual Threat }\end{array}$ & 0.233 & 0.032 & 7.176 & 0.000 & 0.173 & 0.301 & 0.203 \\
\hline & $\begin{array}{l}\text { Traditional Beliefs about Gender } \\
\text { + National Homosexual Threat }\end{array}$ & 0.029 & 0.007 & 4.120 & 0.000 & 0.017 & 0.045 & 0.025 \\
\hline & $\begin{array}{l}\text { Religious/National Beliefs about } \\
\text { Gender }+ \\
\text { Traditional Beliefs about Gender } \\
+ \text { National Homosexual Threat }\end{array}$ & 0.060 & 0.010 & 6.307 & 0.000 & 0.043 & 0.081 & 0.052 \\
\hline Total & & 0.615 & 0.036 & 17.311 & 0.000 & 0.545 & 0.683 & 0.535 \\
\hline
\end{tabular}

